\title{
SLC4A7 Gene
}

National Cancer Institute

\section{Source}

National Cancer Institute. SLC4A7 Gene. NCI Thesaurus. Code C90139.

This gene is involved in cellular homeostasis. 